\title{
The Effect of Restoration Treatment Soils and Parent Tree on Tropical Forest Tree Seedling Growth
}

\author{
R. A. Zahawi1 ${ }^{*}$, C. Eckert ${ }^{2}$, J. M. Chaves-Fallas', L. Schwanitz², J. A. Rosales', K. D. Holl ${ }^{3}$ \\ ${ }^{1}$ Las Cruces Biological Station, Organization for Tropical Studies, San Vito, Costa Rica \\ ${ }^{2}$ Eberswalde University of Applied Sciences, Eberswalde, Germany \\ ${ }^{3}$ Environmental Studies Department, University of California, Santa Cruz, California, USA \\ Email: ${ }^{*}$ zahawi@ots.ac.cr
}

Received 5 January 2015; accepted 22 January 2015; published 26 January 2015

Copyright (C) 2015 by authors and Scientific Research Publishing Inc.

This work is licensed under the Creative Commons Attribution International License (CC BY).

http://creativecommons.org/licenses/by/4.0/

(c) (i) Open Access

\section{Abstract}

Restoration treatments can impact the growth and development of tree seedlings; however, it is often difficult to discern whether responses are driven by changes in microclimate, biotic interactions, or soil properties. To isolate for the latter, we quantified the growth response of four species [Ocotea puberula (Lauraceae); Otoba novogranatensis (Myristicaceae); Pseudolmedia mollis (Moraceae); Senna papillosa (Fabaceae)] grown under similar shade-house conditions in soils collected from 6 - 7 year old active (four species plantation) and passive restoration plots (natural recovery), and nearby reference forest sites in Costa Rica. We also evaluated the role of parent tree by collecting individuals from five mother trees. We measured height, above- and belowground biomass, and determined root: shoot ratios (RSR). Species differed markedly in their responses. Ocotea, and to a lesser extent Pseudolmedia, were largely driven by parent tree. In contrast, Senna showed a strong soil response for all variables with more growth in active than passive restoration soils; reference forest seedlings were typically intermediate. An interaction suggested that some genotypes are more responsive to different soil properties than others. Otoba had higher soil-driven RSR in both restoration treatments. Surprisingly most soil nutrients, including \%N, were similar or significantly lower in active restoration soils, suggesting that seedlings are responding to differences in soil microbial communities or more labile nutrients (e.g., $\mathrm{NH}_{4}+$ and $\mathrm{NO}_{3}-$ ). Active restoration appears to facilitate the growth of other species by improving certain soil properties. Additionally, genotypes are an important driver of seedling vigor and some species may be more responsive to subtle differences in soil properties than others.

\footnotetext{
${ }^{*}$ Corresponding author.
}

How to cite this paper: Zahawi, R. A., Eckert, C., Chaves-Fallas, J. M., Schwanitz, L., Rosales, J. A., \& Holl, K. D. (2015). The Effect of Restoration Treatment Soils and Parent Tree on Tropical Forest Tree Seedling Growth. Open Journal of Forestry, 5 , 154-161. http://dx.doi.org/10.4236/ojf.2015.52015 


\section{Keywords}

\section{Active Restoration, Costa Rica, Forest Recovery, Passive Restoration, Tropical Forest}

\section{Introduction}

Forest restoration efforts typically include the practice of planting tree seedlings to increase canopy cover and accelerate the pace of forest recovery (Chazdon, 2008; Lamb, Erskine, \& Parrotta, 2005). The restoration strategy selected, as well as the density of planting and species selection, can have strong effects on the growth of planted seedlings, subsequent naturally establishing seedlings, or individuals introduced as part of later enrichment planting efforts (Cole, Holl, Keene, \& Zahawi, 2011; Paquette, Bouchard, \& Cogliastro, 2006; Schweizer, Gilbert, \& Holl, 2013). Seedling growth can be affected by a number of factors among themsite-specific biotic and abiotic soil variables (Aldrich-Wolfe, 2007; Butterfield, 1996; Lawrence, 2003; Paul, Catterall, Pollard, \& Kanowski, 2010), herbivory (Gerhardt, 1993; Holl \& Quiros-Nietzen, 1999), provenance or genotype (Iakovoglou, Misra, Hall, \& Knapp, 2007), and competition with or facilitation by existing vegetation (Gomez-Aparicio, 2009; I. C. G. Vieira, Uhl, \& Nepstad, 1994).

Survival and growth of tree seedlings are strongly affected by the type of habitat in which they are planted (e.g., Benitez-Malvido, Martinez-Ramos, Camargo, \& Ferraz, 2005; Cole et al., 2011; Raman, Mudappa, \& Kapoor, 2009; D. L. M. Vieira, Scariot, \& Holl, 2007). For example, Camargo, Ferraz, and Imakawa (2002) found considerable variation in seedling survival and growth after direct-seeding species in pasture, secondary and mature forest in the Brazilian Amazon, and responses were largely species specific. In turn, past research at our study site found that seedling allocation to above- and below-ground biomass was strongly influenced by the restoration treatment (Cole et al., 2011). It was unclear, however, whether differences in allocation and/or growth rates were driven by in situ microclimatic conditions (e.g., light or water availability), biotic interactions, or by differences in nutrient availability. Numerous tropical fertilization studies have shown a seedling response effect to enhanced nutrient availability in both greenhouse and field experiments (e.g., Davidson et al., 2004; Gehring, Denich, Kanashiro, \& Vlek, 1999; Lawrence, 2003; Singh, Jha, \& Singh, 2000) but these studies do not consider the effect of restoration treatments on soil properties. Paul et al. (2010) controlled for this by growing seedlings under greenhouse conditions using soils harvested from several tropical forest restoration and reference sites in Australia. Although they found differences, they were largely attributed to potential allelopathic properties in soils at one habitat and to within habitat type differences in $\mathrm{pH}$ and nitrate rather than a result of restoration treatments per se.

It is well known that the genetic stock or seedling provenance of a particular species can determine its degree of adaptability to a particular set of conditions (e.g., Iakovoglou et al., 2007; Khurana \& Singh, 2001; Raddad, 2007; Ruiz et al., 2013). As such, genotype is considered important in restoration practice and it has been factored into some tropical reforestation studies (Butterfield, 1996; Nichols, Rosemeyer, Carpenter, \& Kettler, 2001). Nonetheless it is rarely tested directly in restoration (e.g., Bischoff, Steinger, \& Muller-Scharer, 2010), and the potential response of genotype to different restoration treatments has not been evaluated.

The goal of this study was to determine whether restoration treatment, through the alteration of soil properties, could impact the growth response of native tree seedlings. We also evaluated the role of parent tree. We used the framework from a large-scale and long-term restoration project in southern Costa Rica (Cole, Holl, \& Zahawi, 2010; Holl, Zahawi, Cole, Ostertag, \& Cordell, 2011; Zahawi, Holl, Cole, \& Reid, 2013), where 13 - 1-ha sites were established between 2004 and 2006 in a mixed-agricultural landscape. The restoration treatments include a passive strategy (no seedlings planted) and an active strategy (mixed-species tree plantation of four species, of which two are $\mathrm{N}$-fixers). Aside from the potential impact of leguminous trees on soil $\mathrm{N}$ through fixation, past research in these sites and nearby younger secondary forests (Celentano et al., 2010) showed that: 1) litter fall biomass was lower in passive plots than active restoration or secondary forest; 2 ) leaf fall $\mathrm{N}$ concentration was highest in active restoration plots; and 3) leaf fall $\mathrm{Ca}, \mathrm{Mg}$, and $\mathrm{K}$ were highest in secondary forest. In the current study, we compared the growth of four native tree species in soils collected from passive restoration, active restoration, and reference forest sites. To control for environmental factors we ran the study in a controlled greenhouse setting. 


\section{Methodology}

This study was carried out between November 2012 and May 2013 in the greenhouse facilities of the Las Cruces Biological Station (LCBS; 847'7"N; 82 57'32"W) in Coto Brus county, southern Costa Rica. The field station is located at $1200 \mathrm{~m}$ ASL and receives a mean annual rainfall of $\sim 4000 \mathrm{~mm}$, with a distinct dry season between January and March. Diurnal temperatures typically range between $13^{\circ} \mathrm{C}-26^{\circ} \mathrm{C}$.

Soils were collected from five active and passive restoration plots, as well as from five nearby reference forest plots within a few days of planting. Restoration sites were 6.5 - $7.5 \mathrm{yr}$ old at the time of soil collection. Passive restoration sites were dominated by a mix of pasture grasses with scattered shrubs and small trees. Active restoration sites had a sparse understory and a dense canopy of the four planted tree species: Terminalia amazonia (J.F. Gmel.) Exell [Combretaceae], Vochysia guatemalensis Donn. Sm. [Vochysiaceae], Erythrina poeppigiana (Walp.) Skeels, and Inga edulis Mart. [Fabaceae]. References forests are fragments of the original premontane forest that was present prior to the broad expansion of agriculture in the area starting in the early 1960s. For more details on restoration design and initial plot management see K. D. Holl et al. (2011) and Zahawi et al. (2013).

Soils between 0 - $15 \mathrm{~cm}$ depth were collected from at least five locations within five $50 \times 50 \mathrm{~m}$ plots of each of the three habitat types. Soils were transported to the LCBS greenhouse and mixed with rice straw hulls to enhance drainage. We used $15 \times 20 \mathrm{~cm}$ plastic bags for the study, which were placed on benches to insure proper drainage and prevent predation by rodents.

We tested four native tree species: Ocotea puberula (Rich.) Nees [Lauraceae], Otoba novogranatensis Moldenke [Myristicaceae], Pseudolmedia mollis Standl. [Moraceae], and Senna papillosa (Britton \& Rose) H. S. Irwin \& Barneby [Fabaceae]. Species were chosen that are well represented in forest fragments in the area, and were producing seeds at the time of initiation of the study. Seeds were harvested from at least five mother trees for all species and germinated in trays prior to planting, with the exception of Ocotea and Senna where seedlings were harvested directly beneath mother trees (bare-rooted) and planted immediately into planter bags (Ocotea $\mu$ $=12.4 \pm 3.4 \mathrm{~cm} \mathrm{~cm}$ and Senna $\mu=6.1 \pm 1.4 \mathrm{~cm}$ at time of transplant). For Senna, only three mother trees were located.

Five seedlings (one from each mother tree)/treatment/site were transplanted into bags ( $\mathrm{n}=75$ seedlings/species) and grown under uniform shade cloth conditions. At the end of the study (4 - 6 mo after planting), final height measurements were taken (to the nearest $\mathrm{mm}$ ) and seedlings were harvested and dried at $65^{\circ} \mathrm{C}$ for a minimum of 24 hr to determine above-ground (AGB) and below-ground (BGB) biomass. Root: shoot ratios (RSR) were calculated for all species.

\subsection{Soil Analyses}

In July 2012 we collected 25, 2.5-cm diameter $\times$ 15-cm deep soil cores across each plot. Cores were mixed, air dried, passed through a 2-mm sieve, and analyzed for $\mathrm{pH}$, Bray II P, and major cations using Mehlich III extractions following standard procedures at Brookside Laboratories, Knoxville, OH (see

www.blinc.com/worksheet_pdf/SoilMethodologies.pdf and Gavlak, Horneck, Miller, \& Kotuby-Amarcher, 2003 for details on protocols). Percent C and N were quantified at Brookside Laboratories using an Elementar Vario EL Cube elemental analyzer.

\subsection{Data Analysis}

All species were analysed separately. A two-way ANOVA was used to determine the effects of soil type and parent tree, on height, AGB and BGB, and RSR for each species. A two-way interaction of soil type× parent tree was included in models when possible; for two species (Otoba, Pseudolmedia) interactions with parent tree were not possible due to some seedling mortality. A one-way ANOVA was used to compare soil properties among the three habitats. For all analyses soil collection site was included in the model as a random factor. A post-hoc Tukey HSD LSMeans test was used to determine differences among statistically significant dependent variables when necessary $(p<0.05)$. All statistical analyses were conducted with JMP 10.0 (2012) and standard error is reported throughout.

\section{Results}

Survival of seedlings was high for all species (>95\%), with the exception of Otoba ( 70\%). The latter was 
largely due to a predation event at the onset of the study, which resulted in damage to a number of seedlings, most of which subsequently died and were removed from all further analyses. Mean height and range (95\% quantiles) at the conclusion of the study varied by species Ocotea $(\mu=15.0 \mathrm{~cm}$; $9.5-22.6)$; Otoba $(\mu=15.5 \mathrm{~cm}$; 6.0 - 24.9); Pseudolmedia ( $\mu=7.1 \mathrm{~cm} ; 2.0$ - 13.6); and Senna ( $\mu=10.2 \mathrm{~cm} ; 4.4$ - 17.0), and final above- and below-ground biomass varied considerably by species (Figure 1).

\subsection{Soil Type \& Parent Tree Effects on Growth}

The four species showed markedly different responses to soil type and parent tree (Table 1). Three species showed a response to parent tree. Parent tree affected height primarily and to a lesser extent AGB of Ocotea; height, AGB, and BGB of Pseudolmedia; and only BGB of Senna. In contrast, Senna had a strong response to soil type for all growth measures and Pseudolmedia a significant but weaker response. Senna was the only species to show an interactive effect of soil and parent tree on growth, suggesting that certain parental genotypes are more responsive to treatment differences than others. Senna height was significantly greater inactive restoration and reference forest soils, whereas AGB and BGB were only greater inactive vs. passive restoration soils; biomass values for reference forest soils were intermediate (Table 1, Figure 1). In turn, Pseudolmedia had greater AGB in active vs. passive restoration soils, with reference forest individuals intermediate. Otoba was the only species to show a difference in RSR; interestingly, passive $(0.82 \pm 0.04)$ and active $(0.82 \pm 0.04)$ restoration soils resulted in higher mean Otoba RSR as compared to seedlings grown in reference forest soils $(0.60 \pm 0.04)$.

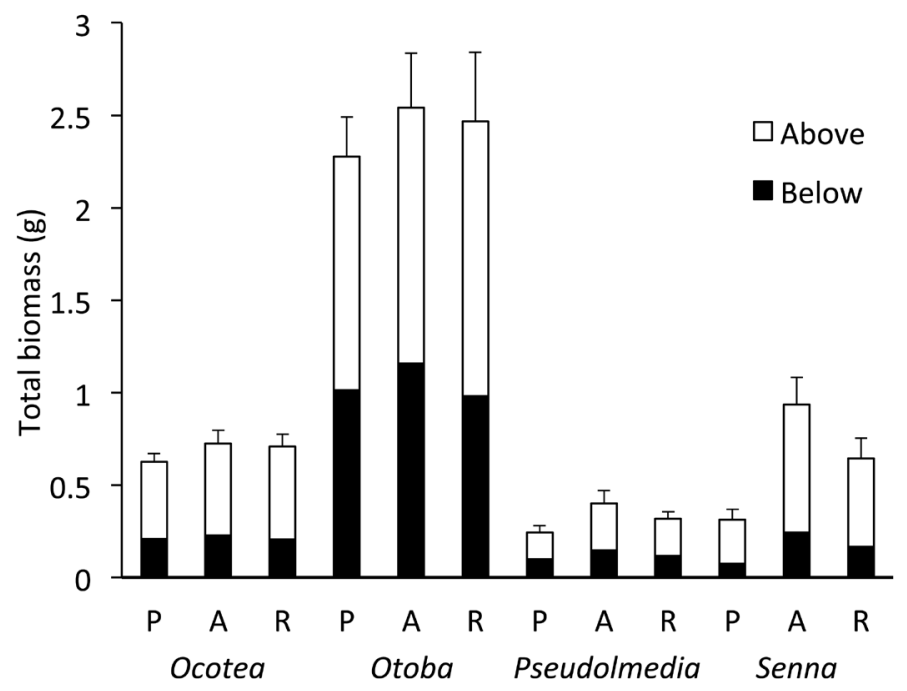

Figure 1. Final above- and below-ground seedling biomass grouped by habitat type ( $\mathrm{p}=$ Passive restoration, $\mathrm{A}=$ Active restoration, $\mathrm{R}=$ Reference forest) and species. Standard error bars for both biomass values combined are shown.

Table 1. Two-way ANOVA comparing height (Ht), above-(AGB) and below-(BGB) ground biomass, and root/shoot ratio (RSR) responses of four tree seedling species to soil type and parent tree. Statistically significant differences $(p<0.05)$ are highlighted in bold; a (-) indicates the interaction was not assessed due to missing parent tree replicates.

\begin{tabular}{ccccccccccccccccc}
\hline & \multicolumn{4}{c}{ Soil Type } & \multicolumn{3}{c}{ Parent Tree } & \multicolumn{5}{c}{ Soil Type $\times$ Parent Tree } \\
\hline Species & Ht & AGB & BGB & RSR & Ht & AGB & BGB & RSR & Ht & AGB & BGB & RSR \\
\hline Ocotea puberula & 0.4126 & 0.2531 & 0.6743 & 0.5171 & $<\mathbf{0 . 0 0 0 1}$ & $\mathbf{0 . 0 2 8 4}$ & 0.1293 & 0.0558 & 0.6423 & 0.2457 & 0.2170 & 0.9117 \\
Otoba novogranatensis & 0.4917 & 0.6453 & 0.7673 & $\mathbf{0 . 0 0 0 6}$ & 0.0716 & 0.1039 & $\mathbf{0 . 0 4 9 3}$ & 0.7684 & - & - & - & - \\
Pseudolmedia mollis & 0.1696 & $\mathbf{0 . 0 3 2 9}$ & 0.1378 & 0.1121 & $\mathbf{0 . 0 1 5 5}$ & $\mathbf{0 . 0 1 5 1}$ & $\mathbf{0 . 0 0 2 4}$ & 0.5977 & - & - & - & - \\
Senna papillosa & $\mathbf{0 . 0 0 0 1}$ & $\mathbf{0 . 0 0 0 2}$ & $\mathbf{0 . 0 0 0 8}$ & 0.3569 & 0.2434 & 0.2041 & 0.3837 & 0.3101 & $\mathbf{0 . 0 3 1 8}$ & $\mathbf{0 . 0 2 2 5}$ & 0.0592 & 0.5983 \\
\hline
\end{tabular}




\subsection{Soil Nutrients}

Half of the measured soil properties (e.g., \%N, \%OM, P, and most micronutrients) were similar across the three habitats (Table 2). CEC, Ca, and Mg were higher in reference forests than both restoration treatment soils, whereas $\mathrm{pH}, \mathrm{K}$, base saturation, and Fe were lowest in active restoration, with passive restoration soils typically intermediate. Cu showed the reverse pattern.

\section{Discussion}

Our results show that active restoration improves soil properties, which can enhance seedling growth of some species. Three of four species showed a direct growth or allocation response to soils from different habitats; in general species grown in active restoration soils had the highest growth and passive restoration the lowest with intermediate values in reference forests. This is an interesting outcome as the seedling development stage in ontogeny typically results in high mortality (e.g., Augspurger \& Kitajima, 1992) and restoration strategies that help seedlings reach the sapling stage more rapidly may be important for the long-term recruitment and survival of tree individuals. The only other greenhouse study to directly evaluate the effect of soil properties collected inactive pasture, restoration and reference forest soils on seedling growth found that species responded more to within treatment than among treatment differences in nutrient availability (Paul et al., 2010).

Directly measured soil variables showed a markedly different pattern to that found for growth. Most variables that differed (e.g., pH, CEC, cations, base saturation), were highest in reference forest and lowest in active restoration soils with values in passive restoration soils either intermediate or similar to active restoration, indicating that restoration treatments retained poorer soil conditions overall as compared to reference forest. The only variable with greater values in active restoration as compared to reference forest was $\mathrm{Cu}$; $\mathrm{Cu}$ can be important for lignin formation (Goransson, 1998), but is not typically a primary limiting nutrient.

Surprisingly, percent soil $\mathrm{N}$ did not vary among habitats, despite notable differences in leaf fall N concentration in active restoration plots, and higher leaf litter in active restoration and young secondary forest plots in our

Table 2. Mean \pm SE for soil properties and micronutrients compared across two restoration treatments and reference forest. Differences among treatments indicated by letter $(\mathrm{p}<0.05)$ and are highlighted in bold.

\begin{tabular}{|c|c|c|c|c|}
\hline \multicolumn{5}{|c|}{ Soil Type } \\
\hline & Passive Restoration & Active Restoration & Reference Forest & $\mathrm{F}(p)$ \\
\hline C (\%) & $7.29 \pm 1.15$ & $7.84 \pm 1.10$ & $7.85 \pm 1.97$ & $1.13(0.3752)$ \\
\hline N (\%) & $0.58 \pm 0.08$ & $0.66 \pm 0.08$ & $0.62 \pm 0.15$ & $1.23(0.3476)$ \\
\hline OM (\%) & $17.59 \pm 2.57$ & $19.26 \pm 2.65$ & $19.15 \pm 4.87$ & $0.87(0.4595)$ \\
\hline $\mathrm{pH}$ & $5.42 \pm 0.07 \mathrm{ab}$ & $5.24 \pm 0.10 b$ & $5.53 \pm 0.22 \mathrm{a}$ & $8.22(0.0140)$ \\
\hline CEC (meq/100 g) & $13.05 \pm 2.54 \mathrm{~b}$ & $14.16 \pm 3.04 \mathrm{~b}$ & $22.78 \pm 3.06 \mathrm{a}$ & $8.47(0.0133)$ \\
\hline Bray II P (mg/kg) & $10.20 \pm 1.98$ & $8.40 \pm 0.51$ & $11.00 \pm 1.29$ & $1.43(0.3020)$ \\
\hline $\mathrm{Ca}(\mathrm{mg} / \mathrm{kg})$ & $1124 \pm 215 b$ & $1180 \pm 223 b$ & $2112 \pm 88 \mathrm{a}$ & $7.61(0.0176)$ \\
\hline Mg (mg/kg) & $196.8 \pm 25.2 b$ & $171.4 \pm 30.8 \mathrm{~b}$ & $398.3 \pm 24.3 \mathrm{a}$ & $19.89(0.0010)$ \\
\hline $\mathrm{K}(\mathrm{mg} / \mathrm{kg})$ & $177.8 \pm 34.6 \mathrm{a}$ & $84.2 \pm 15.0 \mathrm{~b}$ & $213.0 \pm 27.4 \mathrm{a}$ & $5.36(0.0475)$ \\
\hline $\mathrm{Na}(\mathrm{mg} / \mathrm{kg})$ & $26.80 \pm 0.66$ & $29.80 \pm 1.24$ & $28.00 \pm 2.48$ & $1.80(0.2307)$ \\
\hline Base saturation (\%) & $61.05 \pm 2.12 \mathrm{ab}$ & $55.28 \pm 3.14 b$ & $64.41 \pm 3.55 \mathrm{a}$ & $8.24(0.0140)$ \\
\hline $\mathrm{Fe}(\mathrm{mg} / \mathrm{kg})$ & $68.6 \pm 15.8 \mathrm{ab}$ & $53 \pm 13.74 b$ & $88.75 \pm 25.47 \mathrm{a}$ & $4.77(0.0490)$ \\
\hline Mn (mg/kg) & $22.60 \pm 7.97$ & $23.80 \pm 11.66$ & $25.50 \pm 3.71$ & $0.02(0.9834)$ \\
\hline $\mathrm{Cu}(\mathrm{mg} / \mathrm{kg})$ & $7.42 \pm 0.7 \mathrm{a}$ & $7.51 \pm 0.72 \mathrm{a}$ & $5.48 \pm 0.51 b$ & $7.00(0.0232)$ \\
\hline Zn (mg/kg) & $2.46 \pm 0.80$ & $1.87 \pm 0.37$ & $3.24 \pm 0.62$ & $1.10(0.3795)$ \\
\hline $\mathrm{Al}(\mathrm{mg} / \mathrm{kg})$ & $1912 \pm 113$ & $2035 \pm 96$ & $1716 \pm 74$ & $3.29(0.1000)$ \\
\hline
\end{tabular}


study sites (Celentano et al., 2011). Increased $\mathrm{N}$ availability may have also occurred through potential fixation by planted legumes (Nichols \& Carpenter, 2006); interestingly, the latter study reported a similar lack of difference in soil $\mathrm{N}$ despite higher growth rates of planted seedlings. Wood, Lawrence, Clark, and Chazdon (2009) found a strong response to leaf litter addition in a lowland wet forest with enhanced $\mathrm{N}$ and $\mathrm{P}$ reported in the subsequent litter as well as increased litter production, but no difference in incremental growth of trees over 2 yr. The apparently contrasting trends in seedling growth rates and soil nutrients in these and our study can be explained two ways. First, a meta-analysis of greenhouse fertilization studies showed that seedlings often respond to nutrient additions in high light conditions by accumulating higher nutrient concentrations in their leaves, rather than responding with increased growth (Lawrence, 2003). Second, there may have been differences in more labile forms of $\mathrm{N}$ (e.g., nitrate, ammonia), microbial community activity or composition (Araujo et al., 2013), allelopathic chemicals (Paul et al., 2010), or mycorrhizal inoculum potential (Allen, Allen, Egerton-Warburton, Corkidi, \& Gomez-Pompa, 2003) that could have affected growth responses none of which we measured.

Similar growth responses were reported in a direct-seeding experiment by Cole et al. (2011) who planted directly into our restoration plots. Seedlings had greater final biomass in active restoration sites as compared to young secondary forest or passive plots after 2-yr, but the study also reported higher RSR in passive restoration sites suggesting that nutrient limitation maybe impeding the development of seedlings in these habitats. Surprisingly, only Otoba showed a difference in RSR in our study, and the pattern was slightly different with higher RSR in both restoration soil types as compared to reference forest. This disparity, and the lack of differences in RSR in our study in general, could be due to a number of reasons. First, the study by Cole et al. (2011) was done in situ and site-specific factors (such as light availability or herbivory) may have influenced RSR more strongly than nutrient limitation. Second, the current study lasted only six months in order to avoid seedlings from becoming root bound in their containers, which may have not been enough time to develop strong differences in RSR. Finally, although three of four species had exhausted their seed reserves, a number of Pseudolmedia seedlings still retained seeds with visible endosperm reserves present which may have masked potential effects of RSR in this species.

Our results are consistent with many prior studies that have demonstrated the importance of using good genetic stock in restoration projects as some genotypes are more suitable for establishing under stressful conditions than others (Butterfield, 1996; Nichols et al., 2001). Furthermore, Senna showed an interactive effect of parent tree and soil type indicating that some genotypes may respond more positively to altered soil properties than others. Senna was also the only early successional species evaluated in the study and the species may have a greater range of adaptation to respond to subtle differences in nutrient availability than later successional species (Lawrence, 2003). In evaluating the establishment patterns of a common Amazonian tree, Barbosa, Misiewicz, Fine, and Costa (2013) found that genotypes were separated along soil nutrient gradients suggesting that adaptation to local site conditions is important. Certainly research in restoration ecology has demonstrated the importance of using local genotypes (e.g., Bischoff et al., 2010) and whereas using a diversity of genotypes is often suggested in the absence of local availability, adaptation to local conditions of a particular restoration site may be a more important consideration (Jones, 2013; Wilkinson, 2001) than the actual distance from a source population.

Future studies should examine further the role that seed and seedling genetic stock could play in restoration efforts. Although the value of acquiring varied genetic stock is mentioned in a number of forestry studies, few have examined the importance this may play in successful restoration efforts. Additional studies could also compare seedling growth rates under different soil attributes for longer time periods, as well as look at the effects of ongoing nutrient inputs through leaf litter. Whereas a clear signal was found in this 6-mo study, this pattern could shift over time where initial differences in growth at the seedling stage are lost or possibly become more pronounced.

\section{Conclusion}

Results show that actively planting trees as a restoration strategy, and particularly N-fixing species, can affect soil properties with beneficial species-specific responses for establishing tree seedlings. If taken alone, it could be argued that such results may affect the long-term successional trajectory of recovering forests. However, additional site-specific factors such as the degree of light availability in the understory and competition for other limiting resources can also impact the long-term survival and growth of establishing tree seedlings. In addition, 
the genetic stock of seeds or seedlings is an important consideration in restoration work, as some genotypes appear to respond better to stressful conditions than others. Accordingly, active restoration strategies should seek balanced interventions that enhance resource availability and forest recovery without impeding it in other ways.

\section{Acknowledgements}

We thank F. Oviedo-Brenes, S. Coronado, and T. DiRocco for assistance with experimental set up and data collection. Financial support for this project was provided by a NSF grant (DEB 09-18112) and by the University of Eberswalde. We thank the Organization for Tropical Studies and the Las Cruces Biological Station for providing greenhouse space to carry out this study.

\section{References}

Aldrich-Wolfe, L. (2007). Distinct Mycorrhizal Communities on New and Established Hosts in a Transitional Tropical plant community. Ecology, 88, 559-566. http://dx.doi.org/10.1890/05-1177

Allen, E. B., Allen, M. E., Egerton-Warburton, L., Corkidi, L., \& Gomez-Pompa, A. (2003). Impacts of Early- and LateSeral Mycorrhizae during Restoration in seasonal Tropical Forest, Mexico. Ecological Applications, 13, 1701-1717. http://dx.doi.org/10.1890/02-5309

Araujo, A. S. F., Cesarz, S., Leite, L. F. C., Borges, C. D., Tsai, S. M., \& Eisenhauer, N. (2013). Soil Microbial Properties and Temporal Stability in Degraded and Restored Lands of Northeast Brazil. Soil Biology \& Biochemistry, 66, 175-181. http://dx.doi.org/10.1016/j.soilbio.2013.07.013

Augspurger, C. K., \& Kitajima, K. (1992). Experimental Studies of Seedling Recruitment from Contrasting Seed Distributions. Ecology, 73, 1270-1284. http://dx.doi.org/10.2307/1940675

Barbosa, C. E. A., Misiewicz, T. M., Fine, P. V. A., \& Costa, F. R. C. (2013). Plant Ontogeny, Spatial Distance, and Soil Type Influence Patterns of Relatedness in a Common Amazonian Tree. Plos One, 8. http://dx.doi.org/10.1371/journal.pone.0062639

Benitez-Malvido, J., Martinez-Ramos, M. M., Camargo, J. L. C., \& Ferraz, I. D. K. (2005). Responses of Seedling Transplants to Environmental Variations in Contrasting Habitats of Central Amazonia. Journal of Tropical Ecology, 21, 397406. http://dx.doi.org/10.1017/S0266467405002439

Bischoff, A., Steinger, T., \& Muller-Scharer, H. (2010). The Importance of Plant Provenance and Genotypic Diversity of Seed Material Used for Ecological Restoration. Restoration Ecology, 18, 338-348. http://dx.doi.org/10.1111/j.1526-100X.2008.00454.x

Butterfield, R. P. (1996). Early Species Selection for Tropical Reforestation: A Consideration of Stability. Forest Ecology and Management, 81, 161-168. http://dx.doi.org/10.1016/0378-1127(95)03649-0

Camargo, J. L. C., Ferraz, I. D. K., \& Imakawa, A. M. (2002). Rehabilitation of Degraded Areas of Central Amazonia Using Direct Sowing of Forest Tree Seeds. Restoration Ecology, 10, 636-644.

http://dx.doi.org/10.1046/j.1526-100X.2002.01044.x

Celentano, D., Zahawi, R. A., Finegan, B., Ostertag, R., Cole, R. J., \& Holl, K. D. (2011). Litterfall Dynamics under Different Tropical Forest Restoration Strategies in Costa Rica. Biotropica, 43, 279-287. http://dx.doi.org/10.1111/j.1744-7429.2010.00688.x

Chazdon, R. L. (2008). Beyond Deforestation: Restoring Forests and Ecosystem Services on Degraded Lands. Science, 320, 1458-1460. http://dx.doi.org/10.1126/science.1155365

Cole, R. J., Holl, K. D., \& Zahawi, R. A. (2010). Seed Rain under Tree Islands Planted to Restore Degraded Lands in a Tropical Agricultural Landscape. Ecological Applications, 20, 1255-1269. http://dx.doi.org/10.1890/09-0714.1

Cole, R. J., Holl, K. D., Keene, C. L., \& Zahawi, R. A. (2011). Direct Seeding of Late-Successional Trees to Restore Tropical Montane Forest. Forest Ecology and Management, 261, 1590-1597. http://dx.doi.org/10.1016/j.foreco.2010.06.038

Davidson, E. A., De Carvalho, C. J. R., Vieira, I. C. G., Figueiredo, R. D., Moutinho, P., Ishida, F. Y., \& Saba, R. T. (2004). Nitrogen and Phosphorus Limitation of Biomass Growth in a Tropical Secondary Forest. Ecological Applications, 14, S150-S163. http://dx.doi.org/10.1890/01-6006

Gavlak, R., Horneck, D., Miller, R., \& Kotuby-Amarcher, J. (2003). Soil, Plant, and Water Reference Methods for the Western Region (2nd ed.). Corvallis, OR: WREP-125, Western Region Extension Publication.

Gehring, C., Denich, M., Kanashiro, M., \& Vlek, P. L. G. (1999). Response of Secondary Vegetation in Eastern Amazonia to Relaxed Nutrient Availability Constraints. Biogeochemistry, 45, 223-241. http://dx.doi.org/10.1007/BF00993001

Gerhardt, K. (1993). Tree Seedling Development in Tropical Dry Abandoned Pasture and Secondary Forest in Costa Rica. Journal of Vegetation Science, 4, 95-102. http://dx.doi.org/10.2307/3235736 
Gomez-Aparicio, L. (2009). The Role of Plant Interactions in the Restoration of Degraded Ecosystems: A Meta-Analysis across Life-Forms and Ecosystems. Journal of Ecology, 97, 1202-1214.

http://dx.doi.org/10.1111/j.1365-2745.2009.01573.x

Goransson, A. (1998). Steady-State Nutrition and Growth Responses of Betula pendula to Different Relative Supply Rates of Copper. Plant Cell and Environment, 21, 937-944. http://dx.doi.org/10.1046/j.1365-3040.1998.00294.X

Holl, K. D., \& Quiros-Nietzen, E. (1999). The Effect of Rabbit Herbivory on Reforestation of Abandoned Pasture in Southern Costa Rica. Biological Conservation, 87, 391-395. http://dx.doi.org/10.1016/S0006-3207(98)00051-2

Holl, K. D., Zahawi, R. A., Cole, R. J., Ostertag, R., \& Cordell, S. (2011). Planting Seedlings in Tree Islands versus Plantations as a Large-Scale Tropical Forest Restoration Strategy. Restoration Ecology, 19, 470-479. http://dx.doi.org/10.1111/j.1526-100X.2010.00674.x

Iakovoglou, V., Misra, M. K., Hall, R. B., \& Knapp, A. D. (2007). The Effect of Seed Size and Parent Tree on Seed Variables and Seedling Growth of Quercus macrocarpa and Q. alba. Seed Science and Technology, 35, 771-777. http://dx.doi.org/10.15258/sst.2007.35.3.26

Jones, T. A. (2013). When Local Isn’t Best. Evolutionary Applications, 6, 1109-1118. http://dx.doi.org/10.1111/eva.12090

Khurana, E., \& Singh, J. S. (2001). Ecology of Seed and Seedling Growth for Conservation and Restoration of Tropical Dry Forest: A Review. Environmental Conservation, 28, 39-52. http://dx.doi.org/10.1017/S0376892901000042

Lamb, D., Erskine, P. D., \& Parrotta, J. D. (2005). Restoration of Degraded Tropical Forest Landscapes. Science, 310, 16281632. http://dx.doi.org/10.1126/science. 1111773

Lawrence, D. (2003). The Response of Tropical Tree Seedlings to Nutrient Supply: Meta-Analysis for Understanding a Changing Tropical Landscape. Journal of Tropical Ecology, 19, 239-250. http://dx.doi.org/10.1017/S0266467403003274

Nichols, J. D., \& Carpenter, F. L. (2006). Interplanting Inga Edulis Yields Nitrogen Benefits to Terminalia amazonia. Forest Ecology and Management, 233, 344-351. http://dx.doi.org/10.1016/j.foreco.2006.05.031

Nichols, J. D., Rosemeyer, M. E., Carpenter, F. L., \& Kettler, J. (2001). Intercropping Legume Trees with Native Timber Trees Rapidly Restores Cover to Eroded Tropical Pasture without Fertilization. Forest Ecology and Management, 152, 195-209. http://dx.doi.org/10.1016/S0378-1127(00)00603-4

Paquette, A., Bouchard, A., \& Cogliastro, A. (2006). Survival and Growth of Under-Planted Trees: A Meta-Analysis across Four Biomes. Ecological Applications, 16, 1575-1589. http://dx.doi.org/10.1890/1051-0761(2006)016[1575:SAGOUT]2.0.CO;2

Paul, M., Catterall, C. P., Pollard, P. C., \& Kanowski, J. (2010). Does Soil Variation between Rainforest, Pasture and Different Reforestation Pathways Affect the Early Growth of Rainforest Pioneer Species? Forest Ecology and Management, 260, 370-377. http://dx.doi.org/10.1016/j.foreco.2010.04.029

Raddad, E. A. Y. (2007). Ecophysiological and Genetic Variation in Seedling Traits and in First-Year Field Performance of Eight Acacia senegal Provenances in the Blue Nile, Sudan. New Forests, 34, 207-222. http://dx.doi.org/10.1007/s11056-007-9049-4

Raman, T. R. S., Mudappa, D., \& Kapoor, V. (2009). Restoring Rainforest Fragments: Survival of Mixed-Native Species Seedlings under Contrasting Site Conditions in the Western Ghats, India. Restoration Ecology, 17, 137-147. http://dx.doi.org/10.1111/j.1526-100X.2008.00367.x

Ruiz, V. E., Meloni, D. A., Fornes, L. F., Ordano, M., Hilal, M., \& Prado, F. E. (2013). Seedling Growth and Water Relations of Three Cedrela Species Sourced from Five Provenances: Response to Simulated Rainfall Reductions. Agroforestry Systems, 87, 1005-1021. http://dx.doi.org/10.1007/s10457-013-9615-z

Schweizer, D., Gilbert, G. S., \& Holl, K. D. (2013). Phylogenetic Ecology Applied to Enrichment Planting of Tropical Native Tree Species. Forest Ecology and Management, 297, 57-66. http://dx.doi.org/10.1016/j.foreco.2013.02.012

Singh, A., Jha, A. K., \& Singh, J. S. (2000). Effect of Nutrient Enrichment on Native Tropical Trees Planted on Singrauli Coalfields, India. Restoration Ecology, 8, 80-86. http://dx.doi.org/10.1046/j.1526-100x.2000.80011.x

Vieira, D. L. M., Scariot, A., \& Holl, K. D. (2007). Effects of Habitat, Cattle Grazing and Selective Logging on Seedling Survival and Growth in Dry Forests of Central Brazil. Biotropica, 39, 269-274.

http://dx.doi.org/10.1111/j.1744-7429.2006.00246.x

Vieira, I. C. G., Uhl, C., \& Nepstad, D. (1994). The Role of the Shrub Cordia multispicata Cham. as a "Succession Facilitator” in an Abandoned Pasture, Paragominas, Amazonia. Vegetatio, 115, 91-99.

Wilkinson, D. M. (2001). Is Local Provenance Important in Habitat Creation? Journal of Applied Ecology, 38, $1371-1373$. http://dx.doi.org/10.1046/j.0021-8901.2001.00669.x

Wood, T. E., Lawrence, D., Clark, D. A., \& Chazdon, R. L. (2009). Rain Forest Nutrient Cycling and Productivity in Response to Large-Scale Litter Manipulation. Ecology, 90, 109-121. http://dx.doi.org/10.1890/07-1146.1

Zahawi, R. A., Holl, K. D., Cole, R. J., \& Reid, J. L. (2013). Testing Applied Nucleation as a Strategy to Facilitate Tropical Forest Recovery. Journal of Applied Ecology, 50, 88-96. http://dx.doi.org/10.1111/1365-2664.12014 
Scientific Research Publishing (SCIRP) is one of the largest Open Access journal publishers. It is currently publishing more than 200 open access, online, peer-reviewed journals covering a wide range of academic disciplines. SCIRP serves the worldwide academic communities and contributes to the progress and application of science with its publication.

Other selected journals from SCIRP are listed as below. Submit your manuscript to us via either submit@scirp.org or Online Submission Portal.
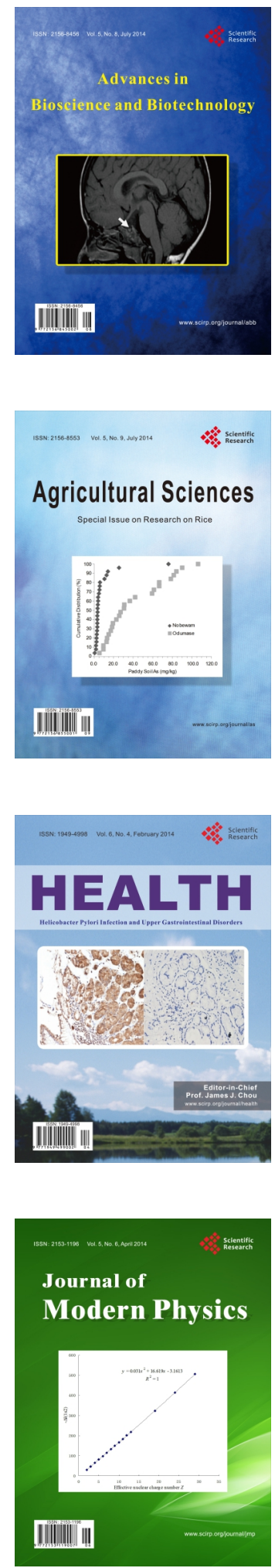
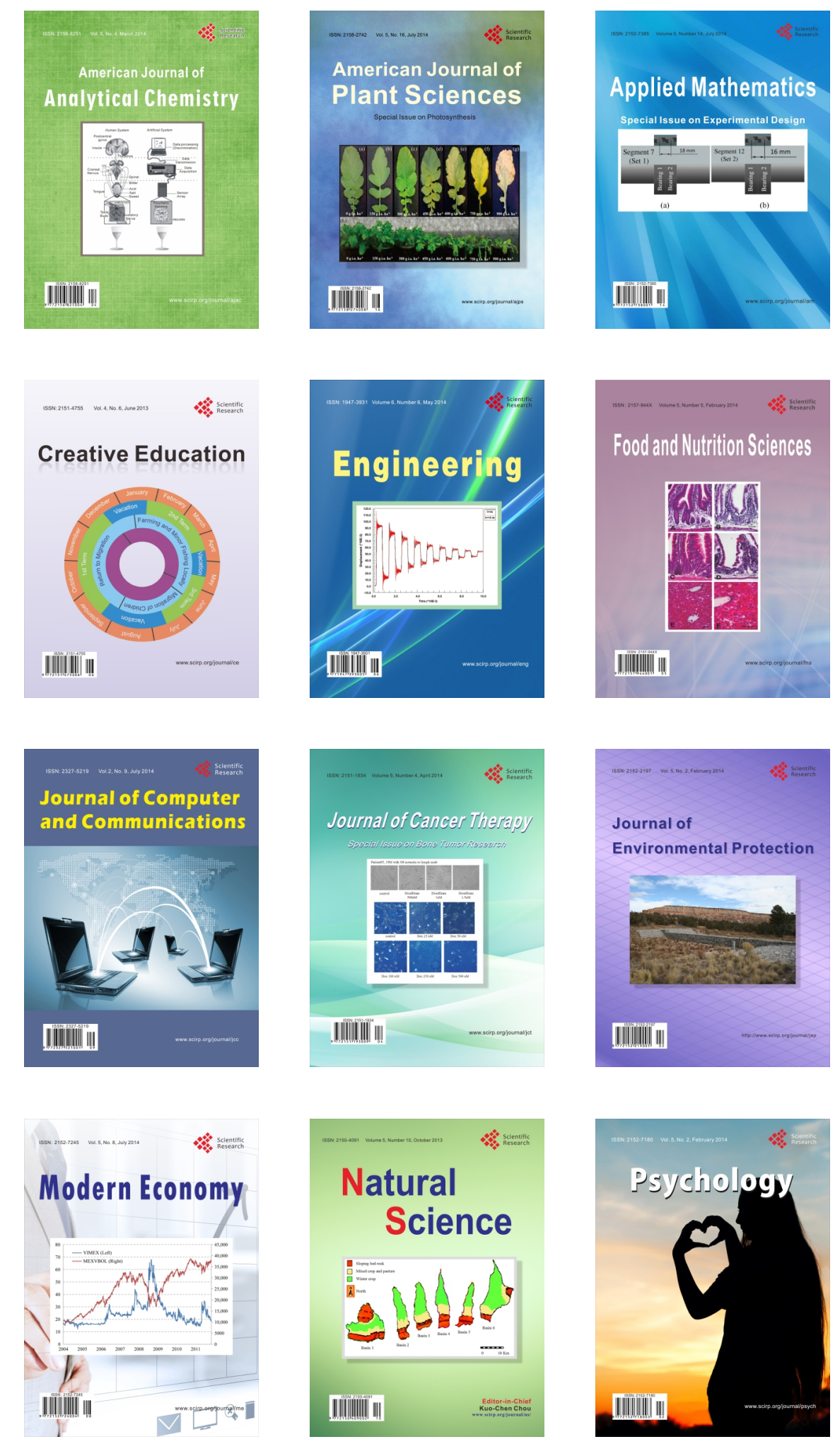